Kuno Lorenz

Von der dialogischen Logik zum dialogischen Konstruktivismus 



\section{Kuno Lorenz}

Von der dialogischen

Logik zum

dialogischen

Konstruktivismus

DE GRUYTER 
ISBN 978-3-11-066674-8

e-ISBN (PDF) 978-3-11-067030-1

e-ISBN (EPUB) 978-3-11-066692-2

Library of Congress Control Number: 2019957966

Bibliografische Information der Deutschen Nationalbibliothek

Die Deutsche Nationalbibliothek verzeichnet diese Publikation in der Deutschen Nationalbibliografie; detaillierte bibliografische Daten sind im Internet über http://dnb.dnb.de abrufbar.

(C) 2021 Walter de Gruyter GmbH, Berlin/Boston

Satz: Integra Software Services Pvt. Ltd.

Druck und Bindung: CPI books GmbH, Leck

www.degruyter.com 